\title{
長周期ねじれ振動が人体の視覚知覚に及ぼす影響 \\ EFFECTS OF LONG PERIOD TORSIONAL MOTION ON HUMAN VISUAL PERCEPTION
}

\author{
新 藤 智*, 後藤 剛 史** \\ Satoshi SHINDO and Takeshi GOTO
}

\begin{abstract}
The authors have carried out studies about human visual perception for torsional motion. The crucial points in this approach are the visual perception of the torsional motion, the relation between the visual perception and the physical perception as well as the comparison of evaluation standards with the results of the experiments. The authors come to a following conclusion:

1. Measuring the degree of motion with a scale in angular velocity, the human perception threshold appears to be independent of the frequency.

2. Average human perception of torsional motion is $0.79[\mathrm{mrad} / \mathrm{s}]$.

3. Visual perception is more sensitive than physical perception.

4. Visual perception threshold of the experiments are lower than the numerical values of standards.
\end{abstract}

Keywords: Long period motion, Torsional motion, Human perception of motion,

Visual perception, Physical perception, Visual simulator

長周期振動，かじれ振動，振動知賞，梘賞知賞，体感知覚，規覚シミュレーター

\section{1 はじめに}

これまでに行われてきた風摇れを対象とする高層建筇物の居住 性に関する研究は、動摇実験装置を用いた研究ばかりでなく、実際 の建築物内で動摇発生時に行われたアンケート調査もあり、世界各 国の振動基準ならびに指針を制定する祭にデータとして活用され ている。しかし、図 1 に示すように、それら人体の振動感覚に関す る既往研究のほとんどは並進振動の体感知覚を対象としており、权 じれ振動および視覚負荷を伴った研究は極めて少ないのが現状で ある。

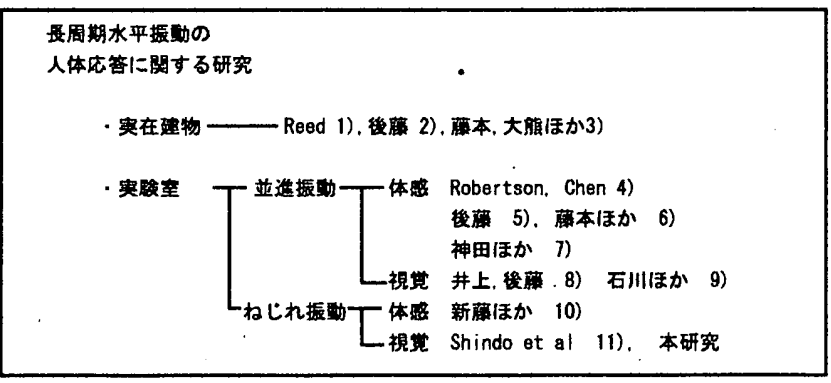

図 1 既往研究と本研究の位置付け
しかし、実存高層建築物には並進振動とねじれ振動が同時に生じる

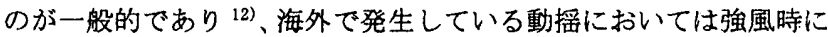
「摇九をはっきりと知覚することが出来、船のデッキにいるような 感じで真っ直ぐ歩くには神経を集中する必要があった」とされ、特 にねじれ振動はその動摇時に動摇する空外景観を眺めていると居 住者に大きな不安を与える等の支障が生じることが高層建築物に 関する国際会議において報告されている ${ }^{13)}$ 。そのような指摘がある

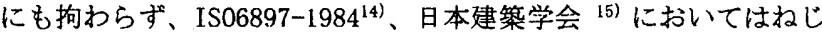
れ振動の要素は加味されていない。またヨーロッパ鋼構造連合

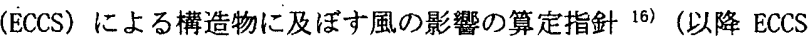
指針と記す)におけるねじれ振動に対しての提示に関しても、その 数値の人体への具体的な影響に関する記述は見られない。そこで、 筆者らはねじれ振動における人体の振動知喾に関する研究に着手 した。その主な対象は視覚知覚と体感知覚である。視覚知覚に関す る建築物の振動時の窓外景観提示方法としては、撮影した原画像を 編集し実験用映像とする視覚的振動負荷を採用することとした。本 報告では振動知知覚実験の結果についてについてまず報告を行う。
* 法政大学大学院工学研究科 大学院生・工修

** 法政大学工学部建築学科 教授. 工博
Graduate Student, Graduate School, Construction Eng, Hosei Univ., M. Eng. Prof., Dept. of Architecture, Faculty of Eng., Hosei Univ., Dr. Eng. 
さらに上記 ECCS 指針、N. Isyumov により提案されたねじれ振動に対 する風外力による高層建築物に生じる振動の許容値評価指針 ${ }^{17}$ （以 降 N. Isyumov の提案値と記す）ならびに本研究における実験結果と の比較検叶を行う。

\section{2. 实験概要}

\section{1 实験璜境}

現実の居住空間では人体の様々な感覚機構で複合的に振動を知

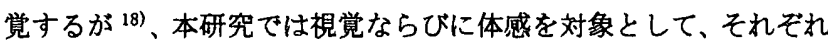
独立させて実験を行った。本研究における視覚知覚とは網膜に映り こんだ映像の動摇を感知する能力を指し、体感知覚とは人間がもつ 感覚のうち身体の傾きや回転などを受容する平衡感覚により振動 を知覚する能力として扱う。梘覚知覚実験においては被験者が滞在 する実験家屋（図 2）自体は一切振動させずに、すなわち体感刺激 を一切与えずに透過スクリーンに投影される実験映像のみを動摇 要素として被験者に与えて実験を行った。また、体感実験では実験 家屋のみを振動させ、透過スクリーンには原画像を未編集のまま投 影した。末編集映像は $0.00417[\mathrm{deg} / \mathrm{s}]$ の等速運動の映像となってお り、視覚知覚実験で使用した動摇に比べ、無視できる程度の変位で ある。被験者の動摇に対しての知営状況を知るために曝露後に 4 段 階（動いていない、気がする程度、かすかに感しる、はっきりと感 じる)のアンケートの回答を求め、被験者の知敩度の検討を行った。 また、実験に使用した映像は 2 種類で、遠くまで見渡せる空外鲸観 を遠景の映像 (写真 1)、視界の一部に近累の建物が入る窓外景観を 遠近混合の映像（写真 2)、とした。

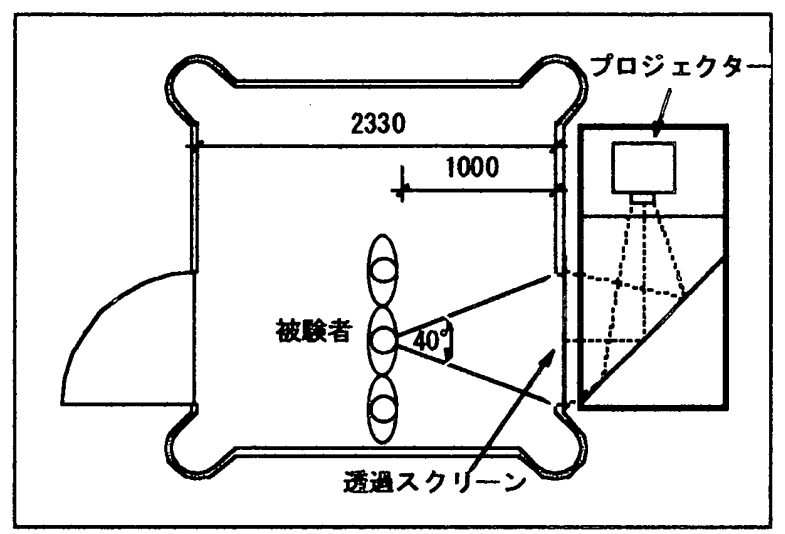

图 2 実験状況

\section{2 实験映像の作成について}

実験用映像は、超高層建筑物最上階からの累観について、ビデオ カメラを超低速で等速回転運動させながら撮影し、その原画像を編 集加工することにより速度変化を持たせた映像を作成する手法を 用いた。それにより、任意周期、任意振幅の実験用映像を自在に提

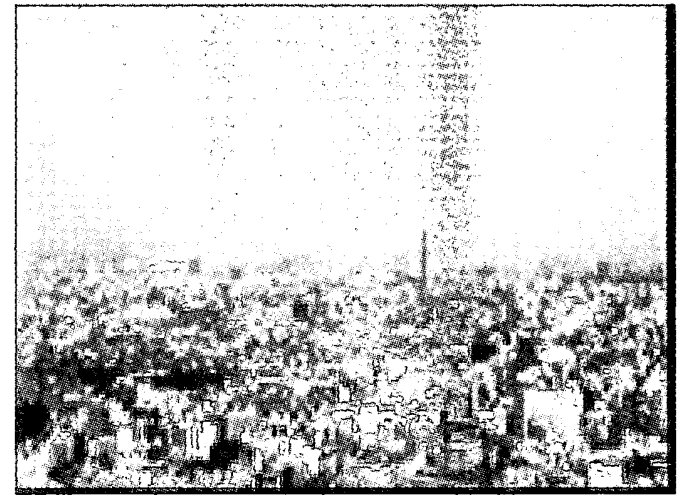

写真 1 遗景映像

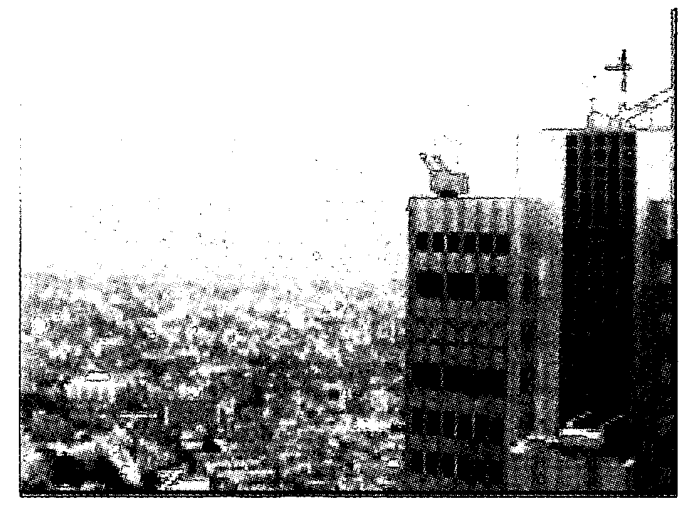

写真 2 德近混合映像

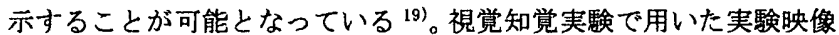
を作成するフローチャートを図 3 に示す。

高層建築物最上階で空外景観を撮影（原画像）

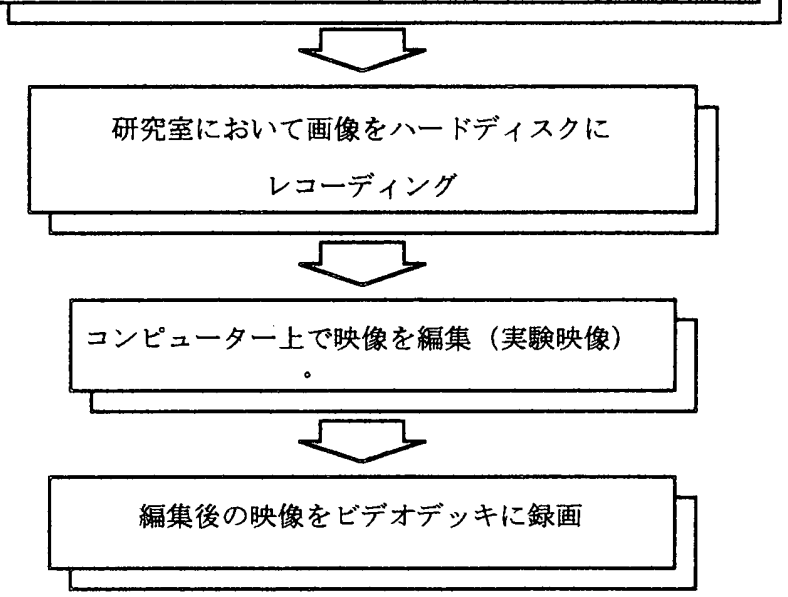

图 3 映像編菓フロー

\section{3 実㪸方法}

実験は 3 力年に渡り、被験者人数は 96 年:男 18 、女 27 人、97 年: 男 28 、女 10 人、98 年: 男 $23 、 女 19$ 人、実験時間はそれぞれ 
の条件で曝露時間 1 分、アンケート記入時間 1 分の計 2 分間とし、 被験者の疲労を考慮に入れ約 30 分間の奏験後 30 分間の休熹をとり 実験を行った。振動数 $0.076 \sim 0.606[\mathrm{~Hz}]$ の長周期振動を実験対象と し、視覚知覚実験では $1.0[\mathrm{mrad} / \mathrm{s}]$ を中心に 0.40 一. $40[\mathrm{mrad} / \mathrm{s}]$ の 間の 6-7 条件、また体感知覚実験では振動装置の作動限界上、各 振動数とも角度变位 $0.1 、 0.2[\mathrm{deg}] の 2$ 条件で実験を行った。また 実験動摇条件の順序は、予備実験の結果から規則性があると摇れを 予測する事ができてしまい正確なアンケート結果が得られないた め、ランダムな 2 パターンを設定した。

\section{3. 知筧闑実験結果並びに考祭}

\section{1 視筧知赏实験結果}

遠鲸の視敩知覚実験における被検者回答を知喾程度別 $(D=$ 動いて いない、C=気がする程度、 $B=$ かすかに感じる、A=はっきりと感じる) に集計し、動摇条件ごとに母数(上記の $A+B+C+D$ )に対する知覚あり $(A+B)$ の回答数の割合を知覚割合として百分率で求め、その結果を ワイブル曲線で回㷌したものを図 4 に、曲線より求められる知覚値 を表 1 に示す。なお、実験室実験であり被験者の反応が過敏な状況 下の結果であることを考虑し、「知覚あり $(\mathrm{A}+\mathrm{B}) 」 に 「 C=$ 気がする程 度」を含めていない。これは本研究室における従来の並進振動実験 における考察手法と同様の処置である。

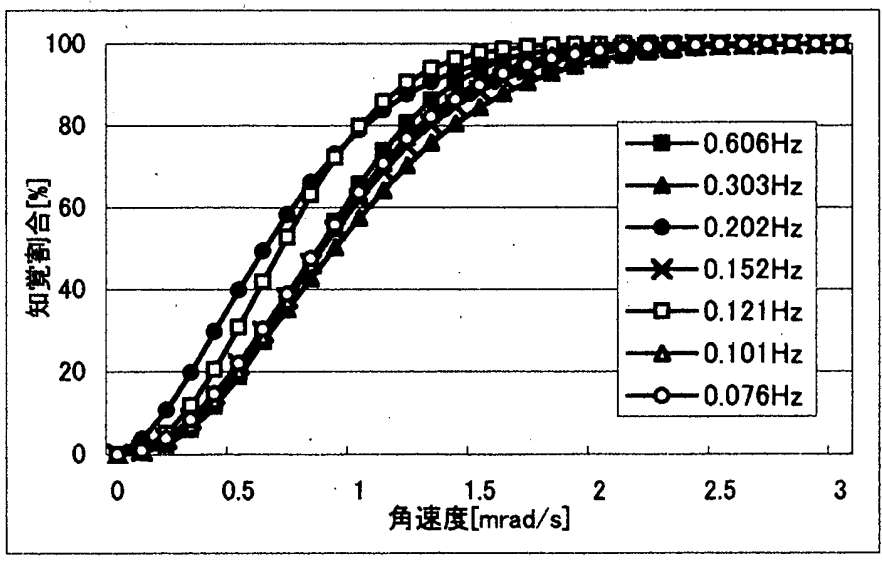

图 4 遠罟視賞知賞实験結果（角速度）

表 1 ねじれ掁動遗暴視觉知赏值

\begin{tabular}{c|c|c|c|c}
\hline 振野数 $[\mathrm{Hz}]$ & 0.076 & 0.101 & 0.121 & 0.152 \\
\hline 50\%知覚值 & $0.83^{*}$ & $0.84^{*}$ & $0.67^{*}$ & $0.84^{*}$ \\
\hline 振勤数 $[\mathrm{Hz}]$ & 0.202 & 0.303 & 0.606 \\
\hline 50\%知覚值 & $0.61^{*}$ & $0.90^{*}$ & $0.83^{*}$ \\
\hline \multicolumn{4}{|c}{ "角速度最大值 $[\mathrm{mrad} / \mathrm{s}]$}
\end{tabular}

図 4 に注目すると全ての振動数条件において回㷌曲線がまとまっ
ており、動摇条件にかかわらずほほ同じ傾向を示している。さらに 上記ワイブル回㷌曲線のデータより予想される $50 \%$ 知覚値（表 1) をもとに解析を進める。独立変数（説明変数）を $50 \%$ 知覚值、従属 变数（目的变数）を振動数、帰無仮説を「50\%知覚値は振動数の变 化に依存しないとし単回帰を行った結果ならびに同回帰の 95\%信 頼区間も合わせて図 5 に示す。

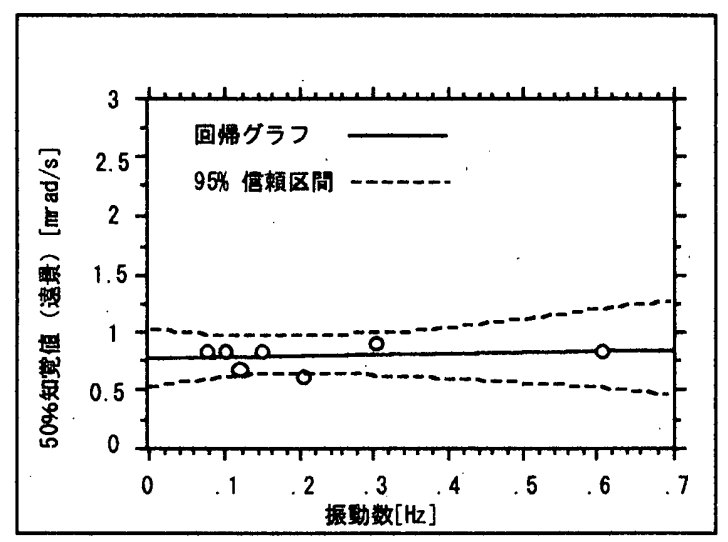

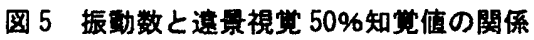

単純直線回㷌の結果 ${ }^{20)} \mathrm{p}$ 值は 0.4227 となり㷌無仮説を菓却する ことが出来ないことから振動数と知覚值との間に相関はなく、また 単回㷌を行ったグラフの傾きがほぼ水平であるとことより、ねじれ 振動における遠景視覚知覚では、振動数が变化しても同一值 (0.75mrad/s) 近傍で $50 \%$ 知覚値に達すると予測できる。この傾向 は振動の大きさを角速度で表した場合に見られる。図 6 に見られる ように角度を用いた場合、50\%知覚值と振動数の関係ではグラフの 傾きが右上がりとなり、角加速度ではそれらの関係は反比例となる。 したがって、ねじれ振動視覚知覚では振動の大きさを弁別するパラ メーターとしては角度あるいは角加速度ではなく、角速度がもっと も相応しいと考える。

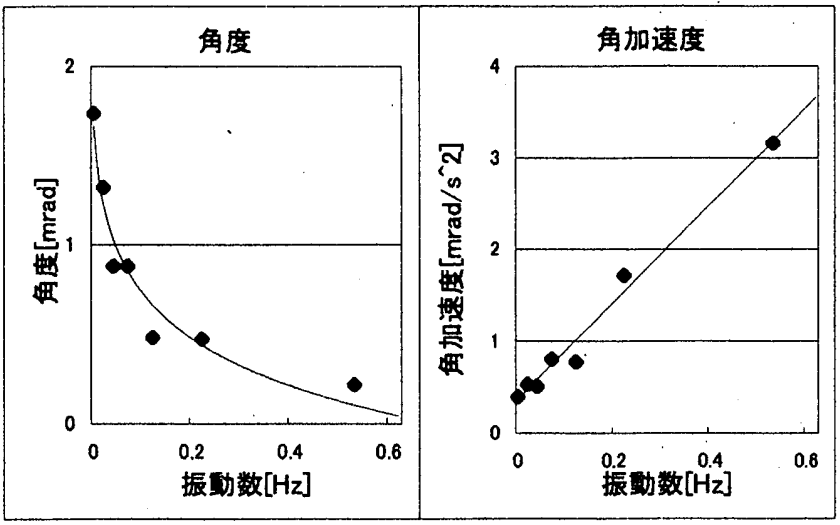

图 6 尺度の逜いによる知営揢合の変化 
次に遠近混合実験の結果も遠景実験と同様に解析を進める。アン ケート集計をもとにワイブル回㷌を行った結果を図 7 にささらに知 覚值を表 2 示す。

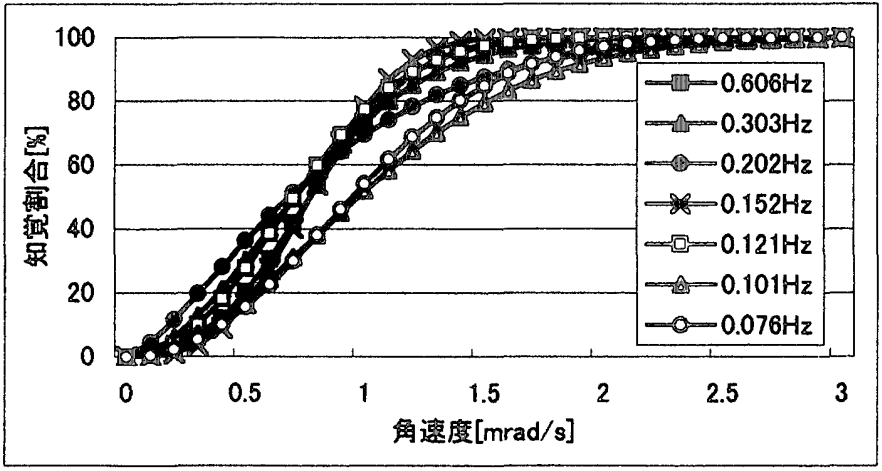

图 7 遗近湿合視賞知當実倹結舆（简速度）

婁 2 ねじれ浱勘荤近湿合視筧知览值

\begin{tabular}{|c|c|c|c|c|}
\hline 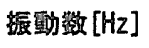 & 0.076 & 0.101 & 0.121 & 0.152 \\
\hline 50\%知筑佃值 & $0.95^{*}$ & $0.97^{\star}$ & $0.71^{*}$ & $0.77^{*}$ \\
\hline 浱動数 [Hz] & 0.202 & 0.303 & 0.606 & \\
\hline 50\%知筧值 & $0.68^{\circ}$ & $0.71^{\circ}$ & $0.77^{\circ}$ & \\
\hline
\end{tabular}

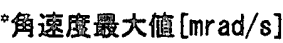

図 7 に着目すると、回㷌曲線は遠景実験とほぼ同じ傾向を示して いる。さらに遠景実験と同様にワイブル回㷌より算出される振動数 毎の $50 \%$ 知覚值を単回帰したものを図 8 に示す。

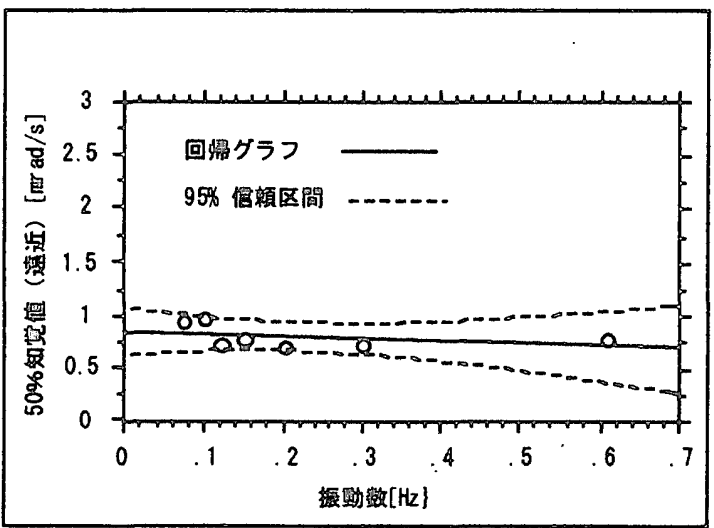

图 8 振動数之 $50 \%$ 知覚值の閣係（宣近混合）

単純直線回㷌の結果、 $\mathrm{p}$ 值は 0.6519 となり、帰無仮説を㐮却す ることが出来ない。したがって、振動数と知覚值との間に相関関倸 はないこととなる。さらに単回帰を行ったグラフの傾きは遠景実験 ほどではないにしろ、ほほ水平に位置付けられている。したがって、 ねじれ振動における遠近混合視覚知覚でも、振動数が変化したとし
てもほぼ同一值近傍で 50\%知覚值に達する傾向は同じといえる。

次に参考までに遠景と遠近混合実験の知覚割合の比較を行うた めに、図 4、7 におけるワイブル曲線を振動数毎に縦軸を知覚割合 [\%]、横軸を角速度 $[\mathrm{mrad} / \mathrm{s}]$ とし、まとめたものを図 9 示す。

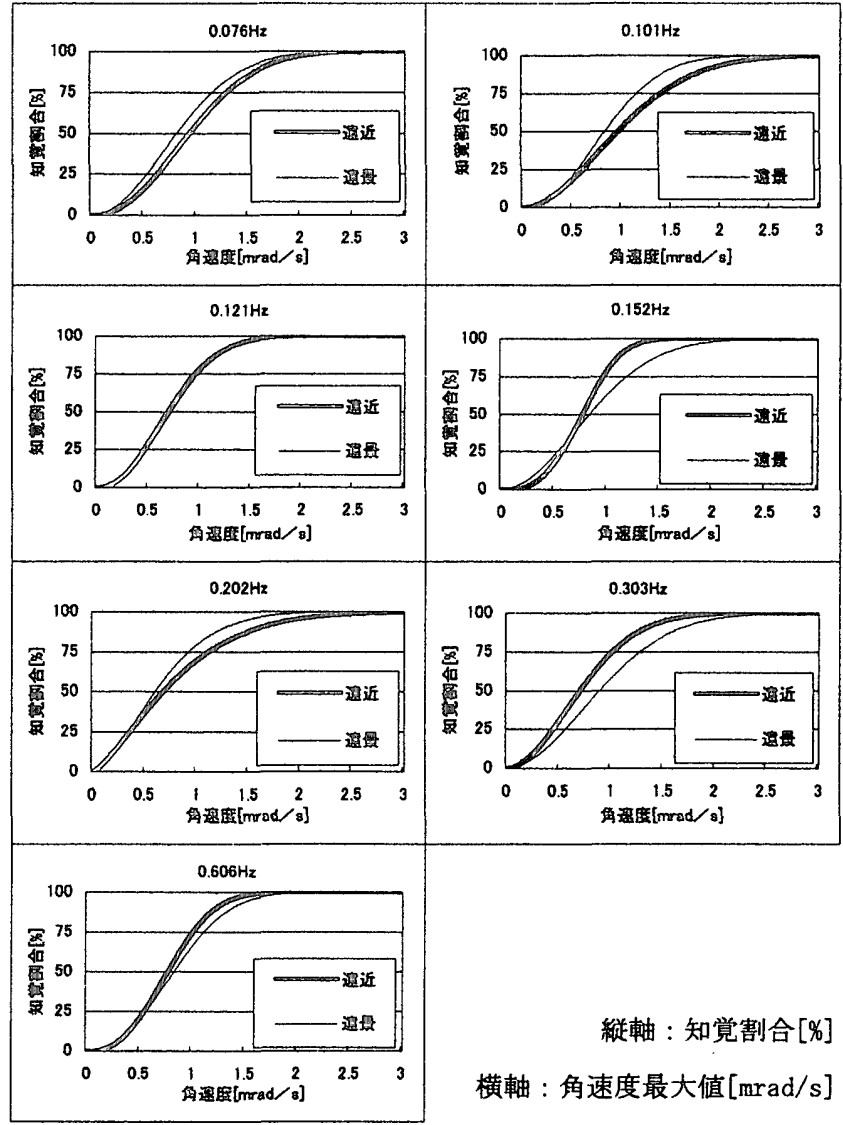

图 9 ねし゚れ桭動における遗異と燠近混合の比較

全ての振動数条件毎に回帰曲線を比較しても極端な違いはみら れない。したがって、ねじれ振動視覚知覚においては視界の一部に 近景の視対象物が入っても知覚割合に差異はみられない。

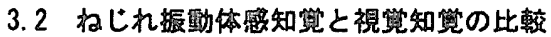

体感知覚実験における知覚反応に関する各振動数としての実験 条件は 3 点（対象実戨を含む）のみであり、ワイブル回㷌を行うこ となく、各結果を遠景実験のワイブル回㷌曲線図にプロットする形 で検討を進める。遠景視覚並びに体感の両実験の結果を振動数每に 示したものが図 10 である。体感実験の条件を角速度表記で行うと 值が幅広くなるためにグラフの横軸の值を図ごとに変えている。

全ての振動数の結果において、視覚知覚の回㷌曲線よりも、体感 実験結果のほうが低い值となっている。また、その傾向は振動数の 増加に伴い顕著な傾向を示している。したがって、ねじれ振動にお いては体感知覚よりも視覚知覚の方が敏感であると言える。 

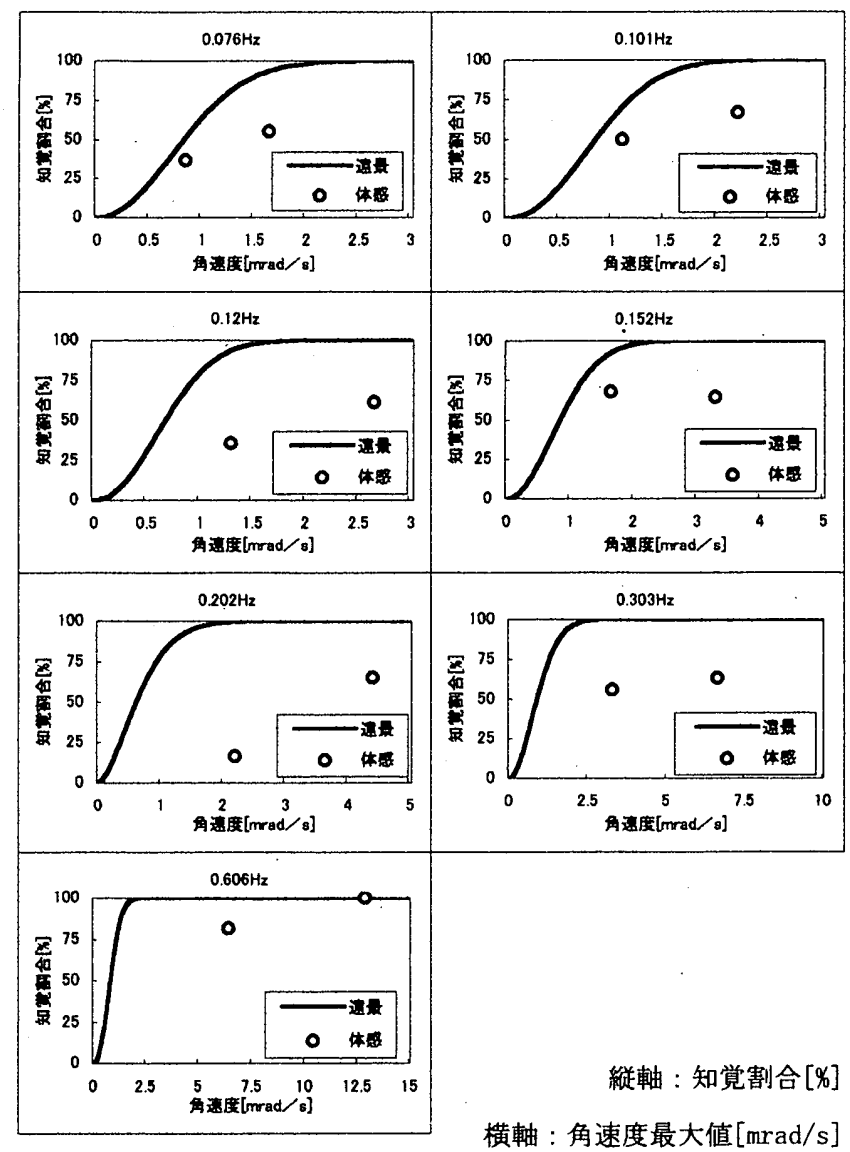

縦軸 : 知覚割合 $[\%]$

横軸 : 角速度最大値 $[\mathrm{mrad} / \mathrm{s}$ ]

\section{图 10 体感知覚と視賞知賞の比較}

\subsection{ECCCS 指針ならびにN. I syumov の提宋値との比較}

本研究で求められた知觉値のうち、遠くまで見渡せる空外景観で ある遠景実験の結果と、ECCS 指針並びに N. Isyumov の提案值 (表 3) との比較検討を行う。N. Isyumov の提案値とは L.G.Griffin ${ }^{21)}$ が求 めた角度表記によるねじれ振動に対しての知覚闌値を基に提案さ

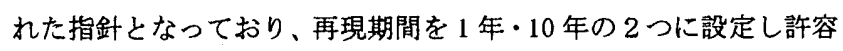
できる応答角速度值を定めているものである。

表 3 ECCS 指針ならびにN. I syumov の提案值

\begin{tabular}{c|c|c}
\hline & 再現期間 & 基淮值 \\
\hline ECCS 指針 & 記述なし & $1.0[\mathrm{mrad} / \mathrm{s}]$ \\
\hline \multirow{2}{*}{$\begin{array}{c}\text { N. Isyumov の } \\
\text { 提案值 }\end{array}$} & 1 年 & $1.5[\mathrm{mrad} / \mathrm{s}]$ \\
\cline { 2 - 3 } & 10 年 & $3.0[\mathrm{mrad} / \mathrm{s}]$ \\
\hline
\end{tabular}

横軸を振動数、縦軸を角速度值とし、本研究のねじれ振動視覚 $50 \%$ 知覚值 (遠景) と上記の両值をプロットしたものを以下の図 11 に示す。

振動数変化に着目すると、ECCS 指針並びに N. Isyumov の提案値

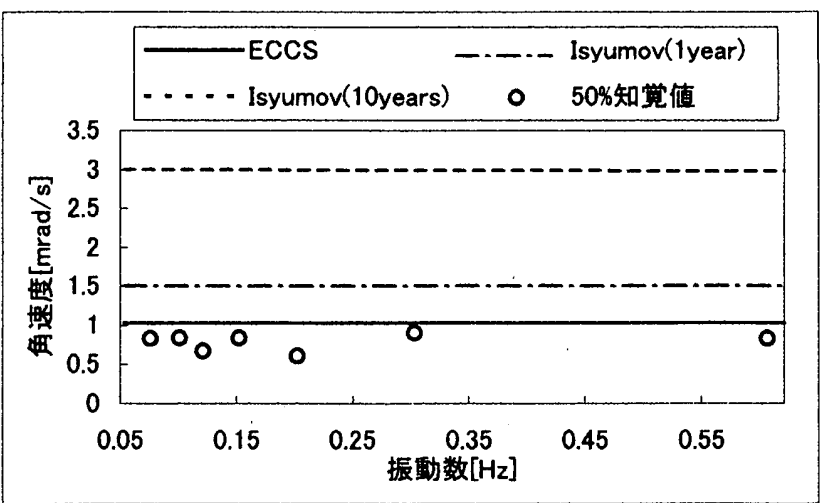

图 11 ねじれ 50\%知覚值と両值との比較

はいずれも建築物の固有振動数にかかわらず同一值が適用されて いる。このことは、本研究における結果とも一致しており、並進振 動に関する体感知覚を対象とした加速度対応の指針に対し、視覚知 覚特有の角速度対忍であることを示していることになる。

角速度の值に着目すると、全ての值が本研究の $50 \%$ 知覚值を上 回っており、最も低い值を設定している ECCS 指針程度の動摇を実 験室で発生させた場合でも、被験者の半数以上が動摇を知覚する可 能性があることが示唆される。また、本研究における $95 \%$ 知覚值(遠 固）の平均值は $1.63[\mathrm{mrad} / \mathrm{s}]$ となっており、N. Isyumov が提案して いる再現期間 1 年の值程度の動摇ではほとんどの被験者が視覚的に 振動を知覚する結果となっている。ただし、実験空での知覚值は一 般の居住状況に比べ被験者が「鋭敏な」状態であり、淔ちに等価対 応が図られるべきではない。しかし、同提案における再現期間 5 年 の值は実験値といえども全条件の $99.9 \%$ の知覚値を超えており、奏 在高層建築物の上層階における居住者のほとんどが空外景観の動 きを視認することが推测される。

\section{4. 結論}

ねじれ振動視覚知覚における、本研究で得られた知見を以下に列 挙する。

(1) ねじれ振動の視覚知覚では動摇の大きさを角速度で表記した 場合、振動数が変化しても5 $50 \%$ 知覚值はほぼ一定値となる。

(2) 遠くまで見渡せる空外景観と視界の一部に近景の視対象物が 入っている空外景観を比較した場合、両者の知覚割合にほとん ど差異は見られない（両者とも50\%知覚値平均：0.79[mrad/s] 近傍)。

(3) 視覚知覚と体感知覚を比較すると、視覚知覚の方が鋭敏である。

(4) ECCS 指針並びに N. Isyumov の提案值ともに全ての振動数で同 一の值を採用しており上記(1)の結論と一致している。

（5) ECCS 指針程度の動摇を実験室で発生させた場合、被験者のほ 
ほ半数以上が動摇を視覚的に知覚する。

(6) N.Isyumov の再見期間 1 年の提案值を動摇条件として実験を行 った場合、ほとんどの被験者が振動を視知覚することになる。

(7) N. Isyumov の提案值における再現期間 10 年の值が実際の高層 建築物で発生した場合、居住者のほとんどが密外固観の動きに より視覚的に振動を知覚する可能性もある。

\section{5. おわりに}

建築物の振動特性はさまさまであり、さらに居住者の状態变化に ともなう知覚值の変動等を考えると十分な考察を果たしたとはい えない。しかし、日本国内の建築物においても、強風時にねじれ振 動が発生し居住者が動摇を知覚している可能性も考えられる。快適 な居住空間を創造するにあたり、日本においても早急にねじれ振動 に対しての指針を検討する必要があると判断される。そこで、(1)本 研究により求められた知覚值をさらに詳細に検討(2)日本国内なら びに世界各国の超高層建築物の振動実測值との比較検討(3)居住者 の状態変化による知覚値の変化、の 3 点を考慮に入れより完成度の 高い研究に昇華させて行くことが今後の課題であると考える。

\section{㩆辞}

ご多忙のところ実験に協力いただいた多くの被験者の方々に感 铸します。さらに、実験及び解析の際に拹力頂いた当研究室の卒業 生に記して感謝の意を表します。

注

本埨文は 1999 年度日本建築学会大会（中国）において発表した内容「高層

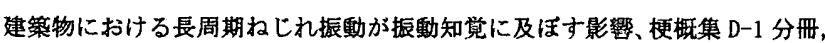
p.311」に加箅修正したものである。

\section{参支献}

1) J. W. Reed: Wind-Induced Motion and Human Discomfort in Tall Buildings, Department of Civil Eng. Research Report R71-42, Massachusetts Institute of Technology, Nov. 1971

2) P. W. Chen and L. E. Robertson: Human Perception Thresholds of Horizontal Motion, J. Str. Div. ASCE, Vol.98, NoST8, Aug. 1972, pp1681-1695

3）後藤剛史: 強風時における超高層ビル゚の摇れに対する居住者の反応につ いて、日本建筑学会大会学術讙演梗概集（近畿）境境、1980 年 9 月

4）藤本盛久、大熊武司ほか：7920 号台風時の建物風圧力および建築振動 についての実測結果 その 5. 建物振動の居住者への影響、日本建築 学会大会学術培演梗概集（近㙨）柫造、1980 年 9 月

5）後藤剧史 : 居住性に観点をおいた高層建築物の振動に関する研究、学位 論文、1975 年

6）“藤本盛久ほが:長周期水平振動を受ける居住者の振動感觉に関する研究、 日本建築学会大会学術譜演梗概集（関東）㩐造、1979年 9 月

7）神田順ほか：長周期水平振動の知喾閶に関する基碇的研究、日本建築学

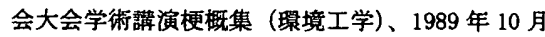

8）井上二郎、後藤剛史ほか：長周期振動における空外景微密外景锶が振動

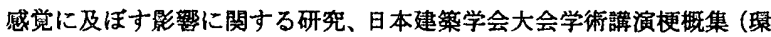
境工学)、1994 年 10 月

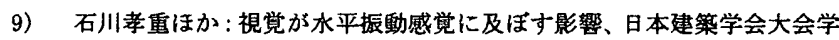
術䯈演梗概集 (眾境工学)、1999 年 9 月

10）新藤智ほか: 高層建筮物における長周期ねじれ振動が振動知覚に及ぼす

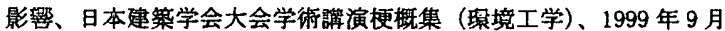

11) S. Shindo, T. Goto: Effect of Hindow View on the Human Perception to Tall Building' $s$ Hind-Induced Torsional Motion, The 1999 International Conference on Tall Buildings \& Urban Habitat, Kuala Lumpur, Malaysia, 1999

12）嶋田健司ほか:高層建築物の風によるねじれ振動、風工学シンポジウム 論文集、No38、1990 年

13) Section, wind Loading and Hind Effects: COUNCIL ON TALL BUILDINGS AND URBAN HABITAT, 67th Regional Conference In conjunction with ASCS Structures Congress XIV, Chicago, I11 inois USA, 1996. 4

14) IS06897-1984: Guidelines for the evaluation of the response of occupants of fixed structures, especially buildings and off-shore structures, to low frequency horizontal motion (0.063 to $1 \mathrm{~Hz}), 1984$

15）日本建築学会 : 建築物の报動に関寸る居住性能指检・同解説、1991年

16) European Convention for Constructional Steel works: Recommendations for the Calculation of wind Effects on Buildings and Structures, Tech. Comn. T12, 1987

17) N. Isyumov : Criteria for Acceptable Wind-induced Motion of Tall Buildings, International Conference on Tall Buildings and Urban Habitat, Rio de Janeiro, 1993.5

18） 3)と同じ

19) S. Satoshi, T. Goto: A Method to Edit Movies for A Visual Simulator and the Effects of the Torsional Motion of High-rise Buildings on Human Perception, Sixth International IBPSA Conference, Building Simulation '99, Kyoto, 1999.9

20）佐藤敏彦、小西宏明：Stat View 4.0 日本語版、株式会社ビー・エヌ・ エヌ、1994 年

21) L. G. Griffin: Serviceability Limit States Under Wind Action, Engineering Journal, American Institute of Steel Construction, First Quarter, 1993

（2001年 6 月 7 日原稿受理，2001年10月23日採用決定） 